\title{
Principal component analysis on fatty acid composition of the meat deriving from calves, young bull and bull of Maremmana breed slaughtered at different age
}

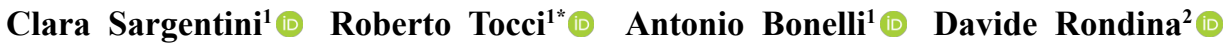

${ }^{1}$ Dipartimento di Scienze e Tecnologie Agrarie, Alimentari, Ambientali e Forestali (DAGRI), Università di Firenze via delle Cascine, Firenze, Italy. E-mail: roberto.tocci@unifi.it. "Corresponding author.

${ }^{2}$ Universidade Estadual do Ceará, Faculdade de Veterinária, Campus do Itaperi, Fortaleza, CE, Brasil.

ABSTRACT: This study evaluated the performance at slaughtering of calves; young bull and bull of Maremmana breed, and compared, through Analysis of Variance (ANOVA) and Principal Component Analysis (PCA) on fatty acid composition, the characteristics of the resulting meat categories: veal, young bull meat and bull meat. The Maremmana cattle is a local endangered breed deriving from Tuscany and Latium. The animals of this study were raised under same conditions in pasture with hay and concentrate supplementations. Eighteen calves of 1214 months, 27 young bulls of 18 months and 14 bulls of 20-24 months were slaughtered in this trial. The performances at slaughtering were considered, and on the meat samples, the chemical analysis and the fatty acid composition were carried out. Results were submitted to ANOVA and PCA, and a Heat map that considered the fatty acid distances among meat typologies was built. Slaughtering performances were better in young bulls and bulls. Chemical composition didn't differ among meat categories. Saturated fatty acids (SFA) were similar among meats, but Monounsaturated (MUFA) and Polyunsaturated fatty acids (PUFA) were lower in veal. Desirable fatty acids and Healthy Indices were better in veal. The results of PCA and Heat map confirmed that veal was quite different from other meats. Maremmana meat deriving from animals of different age has shown overall good characteristics, suitable for the diet of western country population.

Key words: bull meat, fatty acids, PCA, veal, young bull meat.

Análise de componentes principais na composição de ácidos graxos da carne provenientes de vitelos, novilhos e touros da raça Maremmana abatidos em idades diferentes

RESUMO: $O$ objetivo deste trabalho foi avaliar o desempenho no abate de bezerros, novilhos e touros da raça Maremmana, e comparar, por meio de Análise de Variância (ANOVA) e Análise de Componentes Principais (PCA), a composição de ácidos graxos e as características da carne das diferentes categorias: bezerro, novilho e touro. Os animais deste estudo foram criados nas mesmas condições em pastagem com suplementação de feno e concentrado. Foram utilizados 18 vitelos abatidos aos 12-14 meses, 27 novilhos abatidos aos 18 meses e 14 touros abatidos aos 20-24 meses. Sucessivamente foi analisado o desempenho ao abate e as características nutricionais e fisico-quimicas do Musculus longissimus dorsi. Os resultados foram submetidos à análise de variância. Os parâmetros de abate foram melhores em novilhos e touros. A idade ao abate não afetou as características químicas da carne. Não houve diferença em relação à porcentagem de ácidos graxos saturados (SFA), mas a carne de vitela apresentou menor teor de monoinsaturados (MUFA) e poliinsaturados (PUFA). Os ácidos graxos desejáveis e os índices de saúde foram melhores na carne de vitela. A composição de ácidos graxos foi utilizada também, na análise multivariada dos componentes principais e no mapa de calor, como variável discriminatória para os três categorias de carne; essas análises confirmaram que o produto cárneo de vitela é diferente de outros tipos. A carne de Maremmana proveniente de animais de diferentes faixas etárias mostrou boas características gerais, adequadas para a dieta da população do país ocidental.

Palavras-chave: carne de touro, ácidos graxos, análise multivariada dos componentes principais, carne de vitela, carne de novilho.

\section{INTRODUCTION}

Maremmana cattle is an Italian breed present with enough 10.000 animals in 221 farms. The Maremmana breed derives from the Maremma area and it is reared mainly in Lazio (7603 heads in 152 farms) and Tuscany (2404 heads in 63 farms) (ANABIC, 2018).
Maremmana is registered in the Tuscan breed Regional List (Tuscan Regional Law 64/2004) which allows contributions for the Conservation of animal genetic resources for safeguarding biodiversity (Rural Development Program of Tuscany 2014-2020).

Maremmana is an autochthonous breed, deriving from populations of Bos primigenius (TOCCI \& SARGENTINI, 2020). The long horned 
Maremmana cattle lives in Italy since prehistory and, the Bos silvestris known in Roman times, was similar to the modern breed (CIANI et al., 2010). The Maremmana is a rustic and frugal breed well adapted to the hard environment of Maremma, once a marshy and malarious area, from which it takes its name. This breed was used over the past centuries as a draught animal. From the mid-sixties, with the advent of mechanization in agriculture, the Maremmana breed was used for the low-cost production of purebred and crossbreed with specialized meat breeds as Limousin, Chianina and Charolaise (SARGENTINI, 2011).

In the last years, the high interest in animal welfare, in the organic animal products, and the need of healthier diets in Western Country populations, led to more sustainable livestock systems. The rustic breed is more suitable for this purpose, and recent studies confirmed the Maremmana suitability to the extensive farming conditions (TOCCI \& SARGENTINI, 2020).

This study evaluated, through ANOVA and PCA, the meat quality of calves (12- 14 months old), young bulls (14-18 months) and bulls (18-24 months) of Maremmana raised under the same conditions in pasture with hay and concentrate supplementation.

\section{MATERIALS AND METHODS}

\section{Animals}

In this trial were compared the physicalchemical and nutritional characteristics of Musculus longissimus dorsi deriving from Maremmana calves, young bulls and bulls raised in pasture with hay and concentrate supplementation.

The concentrate, having 1 Meat FU kg-1 of DM and $180 \mathrm{~g} \mathrm{~kg}-1 \mathrm{DM}$ of crude protein, were the same for all animals of the trial: barley $(78 \%)$, faba beans $(11 \%)$ and peas $(11 \%)$. The composition of pasture is reported in TOCCI \& SARGENTINI (2020) that studied the meat quality of Maremmana young bulls raised under different farm systems. The calves were raised in pasture until the weaning (7-8 months) with their mothers. From weaning to the 14 months, concentrated feeds $(0.500 \mathrm{~kg}$ $100 \mathrm{~kg}-1$ live weight) were administered. From 15 to 24 months (fattening period) the fresh grass consumption, estimated comparing grazed areas with ungrazed areas, was on average $20.0 \mathrm{~kg} / \mathrm{head} /$ day. In the same age range the concentrate supplementation is reported in TOCCI \& SARGENTINI (2020). The chemical composition of pasture feed is in table 1 . Eighteen calves were slaughtered in a range age of 12-14 months, 27 young bulls were slaughtered at 18 moths, 14 bulls were slaughtered in age range of 2024 months.

\section{Slaughtering parameters and carcass evaluation}

Calves, young bulls and bulls were slaughtered according to the EU Regulation (EUROPEAN PARLIAMENT AND COUNCIL; 2001). Dressing percentage was calculated. The carcasses were then refrigerated at $4{ }^{\circ} \mathrm{C}$ for 15 days, following an experimental design adapted to the usual period of beef aging in Italy. Subsequently, the carcasses were evaluated for the conformation and the fat score, according to the rules of the EU (S) EUROP grid as reported by TOCCI \& SARGENTINI (2020) (15 points obtained by subdividing each EU class in three sub-classes). Fifteen days after slaughtering, from the cut deriving from the eleventh and the thirteenth ribs the Musculus longissimus dorsi samples were taken from each carcass.

\section{Laboratory analysis}

On these samples, the chemical analyses were carried out on samples of calves, young bull and bull meat determining dry matter, ether extract, crude protein and ash (AOAC, 1990). Samples were also analysed for total lipid concentration by gravimetric determination of total lipid extract according to FOLCH et al. (1957), and for quantitative fatty acid composition of total lipids by gas chromatographic separation of methyl esters, comprising C19 as internal standard, on capillary column oven temperature ranging from $164{ }^{\circ} \mathrm{C}$ and $200{ }^{\circ} \mathrm{C}$ with $3{ }^{\circ} \mathrm{C} / \mathrm{min}$ heat increment. The following healthy indices were calculated: MUFA/SFA, PUFA/SFA, $\omega 6 / \omega 3, \mathrm{C} 18: 2 / \mathrm{C} 18: 3, \mathrm{C} 14: 0+\mathrm{C} 16: 0$ (myristic acid + palmitic acid), DFA (unsaturated fatty acids + stearic

Table 1 - Chemical composition of pasture feed $(\mathrm{g} / 100 \mathrm{~g}$ of DM).

\begin{tabular}{lc}
\hline $\mathrm{DM}(\mathrm{g} / 100 \mathrm{~g}$ of feed $)$ & 29.2 \\
\hline $\mathrm{OM} \%$ & 74.6 \\
$\mathrm{ME}(\mathrm{MJ})$ & 8.61 \\
Crude protein & 8.4 \\
Ether extract & 2.9 \\
Crude fibre & 34.2 \\
Ashes & 7.4 \\
MeatFU/kg of DM & 0.56 \\
\hline
\end{tabular}

DM (Dry Matter); ME (Metabolizable Energy); MeatFU (Meat Forage Unit); OM (Organic Matter). 
acid C18:0). AI and TI were calculated according to ULBRICHT \& SOUTHGATE (1991).

\section{Statistical analysis of results}

Data were submitted to Analysis of Variance through the least squares method, using SAS (2013), and considering as source of variance the commercial category established on the basis of the age at slaughter: calves (12-14 months), young bulls (16 -18 months) and bulls (20 -24 months).

A PCA was also performed on fatty acids and healthy indices, to identify which of these parameters characterized the three categories. A Kaiser test was performed to determine the more significant eigenvalues. Furthermore, squared distances between all arrays were used to draw a heat map (HAARMAN et al., 2015), which is a graphical representation of data that uses a system of color-coding to represent different values. Both Discriminant PCA and the heatmap were performed through SAS software.

\section{RESULTS AND DISCUSSION}

Dressing percentage, conformation score and adiposity were lower in the carcass calves (Table 2). The young bull dressing percentage was intermediate between calf and bull, confirming how in Maremmana breed the more suitable age at slaughtering for the dressing percentage (more than $50 \%$ ) is around 18 months. If compared with young bulls, calves aged 12 months have shown similar dressing percentage. The dressing percentage of calves agreed with those reported by SARGENTINI et al. (1996), whereas the results of young bull and bull agreed with SARGENTINI et al. (2010) results. Young bull dressing percentage was similar to that reported by TOCCI \& SARGENTINI (2020) in Maremmana young bulls raised under different farming systems. In a study conducted in different European breeds in calves slaughtered under 12 months (DOMARADZKI et al., 2017), compared with Limousin slaughtered at 11 months, the animals of this study have shown low dressing percentage (TERLER et al., 2014). The young bulls dressing percentage was similar $(51.45 \%$ vs $52.13 \%$ ) to the same parameter reported by DAZA et al. (2014) in Avileña-Negra Iberica catlle individuals slaughtered at about 16 months and fattened under free-range conditions. The conformation score and the fatness degree of Maremmana young bulls were higher than the same parameters reported in AvileñaNegra Iberica carcasses (8.00 vs 6.37 and 5.61 vs 2.63 respectively) but were similar to the Maremmana calf carcass parameters.

The chemical composition in all meat categories did not differ in all considered parameters. The percentage values of moisture, ash, protein and intramuscular fat were on average of $75.10,1.15$, 22.13 and 0.64 respectively. The chemical analysis results agreed with the same parameters reported by SARGENTINI et al. (2010). If compared with the meat of Minhota calves breed slaughtered at 6 and 9 months (ARAÚJO et al., 2020), Maremmana veal has shown lower fat content. The fat content did not agree with the fat content reported by NOGALSKI et al. (2018) in crosses Charolaise x Polish Holstein slaughtered at $15(0.64 \%$ vs $1.81 \%)$ and 18 months $(0.64 \%$ vs $2.64 \%$ ). If compared with the meat of a study carried out on 14, 16 and 18 months old Podolian bulls, the results of the chemical composition was similar, and only the fat content was higher in all categories of the Podolian meat (TARRICONE et al., 2010).

In table 3 the fatty acid content, expressed as percentage of total fatty acids, is shown. SFAcategories were similar among meats. MUFA categories were highest in young bull and bull meat. PUFA categories, both $\omega 3$ and $\omega 6$, were highest in veal. The $\omega 6$ fatty acids (C 20:2, C20:3, C20:4) were highest in veal. Among the $03 \mathrm{C} 18: 3$ and $\mathrm{C} 20: 5$ (EPA) were highest in veal, while $\mathrm{C} 18: 4$ was highest in bull meat. C14:0, in young bull and bull meat, was the most representative SFA. Young bull and bull meat have shown the highest content in MUFA C14:1 and C18:1. The veal results for the Fatty Acid categories expressed as percentage of total lipids agreed with those reported by BOZZI

Table 2 - Performances at slaughtering (Means \pm SEM)

\begin{tabular}{lccc}
\hline & Veal Calves & Young bulls & Bulls \\
\hline Dressing percentage & $49.55 \pm 0.64 \mathrm{~b}$ & $51.45 \pm 0.64 \mathrm{ab}$ & $52.84 \pm 1.03 \mathrm{a}$ \\
Conformation score & $6.11 \pm 0.27 \mathrm{~b}$ & $8.00 \pm 0.27 \mathrm{a}$ & $8.28 \pm 0.43 \mathrm{a}$ \\
Adiposity & $4.66 \pm 0.20 \mathrm{~b}$ & $5.61 \pm 0.20 \mathrm{a}$ & $5.28 \pm 0.32 \mathrm{ab}$ \\
\end{tabular}

$\mathrm{a}, \mathrm{b} \mathrm{P}<0.05$. 
Table 3 - Fatty acid composition expressed as percentage of total lipids in meat (Means \pm SEM).

\begin{tabular}{|c|c|c|c|}
\hline & Veal & Young bulls & Bulls \\
\hline $\mathrm{C} 14: 0$ & $1.2 \pm 0.12 \mathrm{~b}$ & $1.81 \pm 0,10 \mathrm{a}$ & $2,07 \pm 0.14 \mathrm{a}$ \\
\hline $\mathrm{C} 14: 1$ & $0.15 \pm 0.02 b$ & $0.25 \pm 0.02 \mathrm{a}$ & $0.27 \pm 0.03 \mathrm{a}$ \\
\hline C15:0 & $0.40 \pm 0.03$ & $0.42 \pm 0.03$ & $0.45 \pm 0.04$ \\
\hline C16:0 & 20.830 .55 & $21.98 \pm 0.44$ & $22.23 \pm 0.62$ \\
\hline C16:1 & $1.74 \pm 0.13 b$ & $2.26 \pm 0.10 \mathrm{a}$ & $2.09 \pm 0.14 \mathrm{ab}$ \\
\hline $\mathrm{C} 17: 0$ ai & $0.64 \pm 0.04$ & $0.59 \pm 0.04$ & $0.61 \pm 0.05$ \\
\hline $\mathrm{C} 17: 0$ & $1.26 \pm 0.12$ & $1.24 \pm 0.10$ & $0.90 \pm 0.14$ \\
\hline $\mathrm{C} 17: 1$ & $1.35 \pm 0.22$ & $1.51 \pm 0.18$ & $1.81 \pm 0.258$ \\
\hline C18:0 & $16.45 \pm 0.52$ & $16.13 \pm 0.43$ & $16.69 \pm 0.59$ \\
\hline C18:1 & $25.45 \pm 1.09 \mathrm{~b}$ & $29.66 \pm 0.89 \mathrm{a}$ & $30.08 \pm 1.24 \mathrm{a}$ \\
\hline C18.2 & $17.16 \pm 0.89 \mathrm{a}$ & $13.81 \pm 0.73 \mathrm{~b}$ & $14.23 \pm 1.01 \mathrm{ab}$ \\
\hline $\mathrm{C} 18: 3 \omega 3$ & $1.60 \pm 0.09 \mathrm{a}$ & $1.27 \pm 0.08 \mathrm{~b}$ & $1.32 \pm 0.11 \mathrm{ab}$ \\
\hline $\mathrm{C} 18: 4 \omega 3$ & $0.16 \pm 0.03 \mathrm{~b}$ & $0.16 \pm 0.02 b$ & $0.34 \pm 0.03 \mathrm{a}$ \\
\hline $\mathrm{C} 20: 1$ & $0.13 \pm 0.02 b$ & $0.14 \pm 0.02 b$ & $0.24 \pm 0.03 \mathrm{a}$ \\
\hline $\mathrm{C} 20: 2 \omega 6$ & $0.27 \pm 0.03 \mathrm{a}$ & $0.17 \pm 0.03 \mathrm{~b}$ & $0.08 \pm 0.04 \mathrm{~b}$ \\
\hline $\mathrm{C} 20: 3 \omega 6$ & $1.49 \pm 0.10 \mathrm{a}$ & $1.08 \pm 0.09 \mathrm{~b}$ & $0.86 \pm 0.12 b$ \\
\hline $\mathrm{C} 20: 4 \omega 6$ & $6.04 \pm 0.37 \mathrm{a}$ & $4.23 \pm 0.30 \mathrm{~b}$ & $4.28 \pm 0.42 \mathrm{~b}$ \\
\hline C20:5 $\omega 3$ (EPA) & $1.00 \pm 0.09 \mathrm{a}$ & $0.42 \pm 0.08 b$ & $0.15 \pm 0.11 b$ \\
\hline $\mathrm{C} 22: 4 \omega 6$ & $0.48 \pm 0.04$ & $0.38 \pm 0.03$ & $0.41 \pm 0.05$ \\
\hline C22:5 (DPA) & $1.87 \pm 0.13 \mathrm{a}$ & $1.18 \pm 0.11 \mathrm{~b}$ & $1.06 \pm 0.15 \mathrm{~b}$ \\
\hline SFA & $40.98 \pm 0.80$ & $42.81 \pm 0.66$ & $43.48 \pm 0.91$ \\
\hline MUFA & $28.82 \pm 0.94 b$ & $34.01 \pm 0.77 \mathrm{a}$ & $33.68 \pm 1.07 \mathrm{a}$ \\
\hline PUFA $\omega 6$ & $25.43 \pm 1.28 \mathrm{a}$ & $19.97 \pm 1.04 \mathrm{~b}$ & $19.68 \pm 1.45 b$ \\
\hline PUFA $\omega 3$ & $4.78 \pm 0.28 \mathrm{a}$ & $3.22 \pm 0.23 \mathrm{~b}$ & $3.16 \pm 0.31 \mathrm{~b}$ \\
\hline Total PUFA & $30.21 \pm 1.46 \mathrm{a}$ & $23.19 \pm 1.20 \mathrm{~b}$ & $22.84 \pm 1.66 b$ \\
\hline
\end{tabular}

$\mathrm{a}, \mathrm{b} \mathrm{P}<0.05$

MUFA (Monounsaturated Fatty Acids); PUFA (Polyunsaturated Fatty Acids); SFA (Saturated Fatty Acids).

et al. (1998) in Maremmana veal deriving from calves of 12 months old. If compared with the Limousin veal, the Maremmana veal have shown very low SFA and MUFA content (40.98\% vs $47.1 \%$ and $28.82 \%$ vs $34.8 \%$ respectively); the total PUFA $\omega 6$ were very higher in Maremmana veal, whereas PUFA $\omega 3$ were higher in Limousin suckling cows (4.78\% vs 6.26\%) (TERLER et al., 2014). Results of young bull and bull meat agreed with the same parameters reported by SARGENTINI et al. (2010) and with those found by TOCCI \& SARGENTINI (2020). If compared with Marismena young bull meat (NOGALES et al., 2017), SFA and MUFA were lower in Maremmana young bull meat $(42.81 \%$ vs $45.34 \%$ and $34.01 \%$ vs $37.98 \%$ respectively), PUFA $\omega 6$ were higher, whereas the PUFA $\omega 3$ were similar. If compared with young bulls Charolais x Holstein-Friesian (NOGALSKI et al., 2018), SFA and MUFA were lower in the Maremmana young bull meat ( $42.81 \%$ vs $49.05 \%$ and $34.01 \%$ vs $45.94 \%$ respectively). The Maremmana bull meat compared with the bull meat of individuals raised extensively (DE LA FUENTE et al., 2009) has shown lower SFA and MUFA content $(43.48 \%$ vs $44.27 \%$ and $33.68 \%$ vs $42.49 \%$ respectively), while the PUFA content was higher (22.84\% vs $13.24 \%)$. SFA, MUFA, PUFA $\omega 3$ and PUFA $\omega 6$ content in young bull meat agreed with the same parameters reported in Avileña-Negra Iberica calf meat (DAZA et al., 2014).

Considering the fatty acid content expressed as mg per 100 gr of Musculus longissimus thoracis (table 4), SFA, MUFA and PUFA $\omega 6$ have shown higher content in young bull meat, lower in veal, and intermediate in bull meat. The PUFA $\omega 3$ was higher in veal and young bull meat while the UFA content was higher in young bull meat; the total PUFA were highest in young bull meat. The SFA content, in percentage, reported on this study was similar to that found on Jersey, South Devon, Aberdeen Angus, Highland, Simmental, Limousin, Charollais, Asturiana de la Montaña, whereas if considered in mg per 100 gr, 
Principal component analysis on fatty acid composition of the meat deriving from calves, young bull and bull of Maremmana breed... 5

Table 4 - Fatty acid composition expressed as mg per 100 gr of Musculus longissimus thoracis (Means \pm SEM).

\begin{tabular}{|c|c|c|c|}
\hline & Veal & Young bulls & Bulls \\
\hline C14:0 & $9.541 \pm 2.594 b$ & $22.069 \pm 2.118 \mathrm{a}$ & $19.818 \pm 2.941 \mathrm{a}$ \\
\hline C14:1 & $1.557 \pm 0.528 b$ & $3.280 \pm 0420 b$ & $2.634 \pm 0.582 \mathrm{ab}$ \\
\hline $\mathrm{C} 15: 0$ iso & $0.921 \pm 0.290$ & $1.739 \pm 0.230$ & $1.471 \pm 0.319$ \\
\hline ai $\mathrm{C}: 15$ & $1.223 \pm 0.270 \mathrm{~b}$ & $2.473 \pm 0.220 \mathrm{ab}$ & $1.889 \pm 0.306 \mathrm{ab}$ \\
\hline $\mathrm{C} 15: 0$ & $3.016 \pm 0.647$ & $5.065 \pm 0.528$ & $4.310 \pm 0.734$ \\
\hline $\mathrm{C} 16: 0$ iso & $0.557 \pm 0.224$ & $2.381 \pm 0.183$ & $1.952 \pm 0.254$ \\
\hline C16:0 & $148.840 \pm 20.871 \mathrm{~b}$ & $256.682 \pm 17.041 \mathrm{a}$ & $214.764 \pm 23.666 \mathrm{ab}$ \\
\hline $\mathrm{C} 16: 1$ & $12.880 \pm 2.483 b$ & $26.719 \pm 2.027 \mathrm{a}$ & $19.644 \pm 2.815 \mathrm{ab}$ \\
\hline $\mathrm{C} 17: 0$ ai & $4.611 \pm 0.619 \mathrm{~b}$ & $6.906 \pm 0.506 \mathrm{a}$ & $5.553 \pm 0.702 \mathrm{ab}$ \\
\hline $\mathrm{C} 17: 0$ & $8.956 \pm 1.446 b$ & $13.882 \pm 1.181 \mathrm{a}$ & $8.355 \pm 1.639 b$ \\
\hline $\mathrm{C} 17: 1$ & $9.611 \pm 1.973 \mathrm{~b}$ & $16.500 \pm 1.611 \mathrm{a}$ & $16.521 \pm 2.237 \mathrm{ab}$ \\
\hline C18:0 & $117.863 \pm 15.731 \mathrm{~b}$ & $188.962 \pm 12.845 \mathrm{a}$ & $153.713 \pm 17.838 \mathrm{ab}$ \\
\hline C18:1 & $184.685 \pm 33.436 \mathrm{~b}$ & $354.260 \pm 27.300 \mathrm{a}$ & $275.640 \pm 640 a b$ \\
\hline $\mathrm{C} 18.2 \omega 6$ & $114.161 \pm 6.928 b$ & $147.657 \pm 5.657 \mathrm{a}$ & $126.857 \pm 7.856 \mathrm{ab}$ \\
\hline $\mathrm{C} 18: 3 \omega 3$ & $11.248 \pm 1.599$ & $15.334 \pm 1.306$ & $11.897 \pm 1.813$ \\
\hline $\mathrm{C} 18: 4 \omega 3$ & $1.397 \pm 0.319 \mathrm{~b}$ & $2.117 \pm 0.260 b$ & $3.268 \pm 0.362 \mathrm{a}$ \\
\hline C20:1 & $0.606 \pm 0.276 b$ & $1.588 \pm 0.225 \mathrm{a}$ & $2.321 \pm 0.312 \mathrm{a}$ \\
\hline $\mathrm{C} 20: 2 \omega 6$ & $1.832 \pm 0.300 \mathrm{a}$ & $1.666 \pm 0.245 \mathrm{a}$ & $0.586 \pm 0.353 \mathrm{~b}$ \\
\hline $\mathrm{C} 20: 3 \omega 6$ & $10.107 \pm 1.025 \mathrm{ab}$ & $11.607 \pm 0.837 \mathrm{a}$ & $7.680 \pm 1.162 b$ \\
\hline $\mathrm{C} 20: 4 \omega 6$ & $40.535 \pm 3.242$ & $44.678 \pm 2.647$ & $38.049 \pm 3.676$ \\
\hline $\mathrm{C} 20: 4 \omega 3$ & $7.884 \pm 0.791 \mathrm{a}$ & $4.196 \pm 0.646 b$ & $1.156 \pm 0.897 \mathrm{c}$ \\
\hline $\mathrm{C} 20: 5 \omega 3$ (EPA) & $3.193 \pm 0.279 b$ & $4.142 \pm 0.228 \mathrm{a}$ & $3.610 \pm 0.316 \mathrm{ab}$ \\
\hline $\mathrm{C} 22: 4 \omega 3$ & $7.633 \pm 0.370 \mathrm{a}$ & $3.395 \pm 0.302 b$ & $2.597 \pm 0.420 \mathrm{~b}$ \\
\hline C22:5 (DPA) & $14.795 \pm 0.853 \mathrm{a}$ & $11.968 \pm 0.697 \mathrm{~b}$ & $9.235 \pm 0.968 b$ \\
\hline SFA & $288.219 \pm 40.228 b$ & $486.663 \pm 32.846 \mathrm{a}$ & $400.961 \pm 45.615 \mathrm{ab}$ \\
\hline MUFA & $209.254 \pm 36.783 b$ & $402.349 \pm 30.033 a$ & $316.760 \pm 41.708 \mathrm{ab}$ \\
\hline PUFA $\omega 6$ & $174.268 \pm 10.128 b$ & $209.004 \pm 8.269 \mathrm{a}$ & $175.728 \pm 11.484 \mathrm{ab}$ \\
\hline PUFA $\omega 3$ & $38.518 \pm 2.208 \mathrm{a}$ & $37.759 \pm 1.803 \mathrm{a}$ & $29.167 \pm 2.503 b$ \\
\hline Total PUFA & $212.786 \pm 11.144 \mathrm{ab}$ & $246.762 \pm 0.099 \mathrm{a}$ & $204.896 \pm 12.636 b$ \\
\hline UFA & $422.04 \pm 41.424 \mathrm{~b}$ & $649.111 \pm 33.823 a$ & $521.656 \pm 46.970 \mathrm{ab}$ \\
\hline
\end{tabular}

a,b $\mathrm{P}<0.05$

MUFA (Monounsaturated Fatty Acids); PUFA (Polyunsaturated Fatty Acids); SFA (Saturated Fatty Acids); UFA (Unsaturated Fatty acids).

the SFA content was similar to that of Limousin, Piemontese (veal), Asturiana de los Valles (SEVANE et al., 2014). The MUFA percentage reported in this study was similar to that found on Piemontese and Asturiana de la Montaña meat. If expressed as mg per 100 gr of Musculus longissimus thoracis, the MUFA content in Maremmana meat was similar to that found on Limousin and Piemontese veal, and in the meat of Marchigiana, Piemontese, Asturiana de los Valles Asturiana de la Montaña (SEVANE et al., 2013). The percentage of PUFA content was similar to that reported on Piemontese and on Asturiana de los Valles meat, and, if considered in mg per $100 \mathrm{gr}$, the PUFA content in Maremmana meat was similar to that found on South Devon, Simmental, Marchigiana, Asturiana de los Valles meat (SEVANE et al., 2013). The C18:3 n3 content agreed with Holstein and Danish Red meat, whereas the 22:5 n3 content was similar to that of Jersey, South Devon, Aberdeen Angus, Highland, Simmental, Limousin, Charollais, Asturiana de la Montaña meat (SEVANE et al., 2013).

In table 5 the Healthy Indices are shown. The MUFA/SFA ratio was better in young bulls and bulls $(0.79 \pm 0.02$ and $0.78 \pm 0.02$ respectively), while PUFA/SFA was higher in veal $(0.75 \pm 0.04) . \omega 6 / \omega 3$ was higher in young bulls $(6.49 \pm 0.39)$, lower in veal and intermediate in bulls. DFA were higher in veal. TI and AI were lower, more favourable, in veal.

The PUFA/SFA ratio was higher than 0.5 in all categories, and the $\omega 6 / \omega 3$ index, $\mathrm{AI}$ and $\mathrm{TI}$ increased with age. DFA were higher in veal and 
Table 5 - Healthy Indices (Means \pm SEM).

\begin{tabular}{lccc}
\hline & Veal & Young bulls & Bulls \\
\hline C14:0+C16:0 & $22.15 \pm 0.63$ & $23.80 \pm 0.52$ & $24.30 \pm 0.72$ \\
MUFA/SFA & $0.70 \pm 0.02 \mathrm{~b}$ & $0.79 \pm 0.02 \mathrm{~b}$ & $0.78 \pm 0.02 \mathrm{ab}$ \\
PUFA/SFA & $0.75 \pm 0.04 \mathrm{a}$ & $0.55 \pm 0.04 \mathrm{~b}$ & $0.53 \pm 0.05 \mathrm{~b}$ \\
$\omega 6 / \omega 3$ & $5.48 \pm 0.34 \mathrm{~b}$ & $6.54 \pm 0.28 \mathrm{a}$ & $6.49 \pm 0.39 \mathrm{ab}$ \\
$\omega 3 / \omega 6$ & $0.19 \pm 0.01$ & $0.16 \pm 0.01$ & $0.16 \pm 0.01$ \\
C18:2/c18:3 & $11.12 \pm 0.96$ & $11.76 \pm 0.78$ & $11.45 \pm 1.08$ \\
DFA & $75.49 \pm 0.58 \mathrm{a}$ & $73.33 \pm 0.48 \mathrm{~b}$ & $73.21 \pm 0.66 \mathrm{~b}$ \\
TI & $0.67 \pm 0.02 \mathrm{~b}$ & $0.77 \pm 0.02 \mathrm{a}$ & $0.81 \pm 0.026 \mathrm{a}$ \\
AI & $0.43 \pm 0.02 \mathrm{~b}$ & $0.52 \pm 0.02 \mathrm{a}$ & $0.55 \pm 0.02 \mathrm{a}$
\end{tabular}

a, b P $<0.05$

AI (Atherogenicity Index); DFA (Desirable fatty acids); MUFA (Monounsaturated Fatty Acids); PUFA (Polyunsaturated Fatty Acids); SFA (Saturated Fatty Acids); TI (Thrombogenicity Index).

decreased in bull meat. The $\omega 6 / \omega 3$ index has shown optimal ratio in veal; nutritionists claim that the desirable ratio $\omega 6 / \omega 3$ should be enough 5 (ÖZOGUL $\&$ ÖZOGUL; 2007). The $\omega 6 / \omega 3$ ratio agreed with the Jersey, Highland, Limousin and Charollais meat (SEVANE et al., 2013). This parameter did not agree with the $\omega 6 / \omega 3$ ratio found in Avileña-Negra Iberica calf meat (DAZA et al., 2014), that showed higher values (5.48 in Maremmana veal vs 8.84 ).

The higher values of 0.5 PUFA/SFA ratio indicated high PUFA content. This value did not meet with the PUFA/SFA ratio of Avileña-Negra Iberica calf meat (DAZA et al., 2014), that showed lower values (0.50). The AI and TI remained at low levels in all meat categories. The total lipids of the composition changed in function of the age: the palmitholeic and oleic fatty acids; and consequently, the MUFA percentage and MUFA/SFA ratio increased, whereas the PUFA $n 3$ content decreased with the age. The MUFA increasing, mainly due to the oleic fatty acid, was positive because it allows to a cholesterol decrease. The MUFA/SFA ratio in young bull meat was similar to the same parameter found in Avileña-Negra Iberica calf meat (DAZA et al., 2014). Because the decrease of PUFA, and in particular C18:2, DFA decreased with age.

The percentage of fatty acids considered for categories have shown that in PC1, explaining 45.6 $\%$ of the total variability, the young bull and bull meat, on the left, were characterized by MUFA and SFA, while veal, on the right side were characterized by PUFA (Figure 1). The fatty acids expressed as $\mathrm{mg}$ per $100 \mathrm{gr}$ (Figure 2) mainly identified in PC1

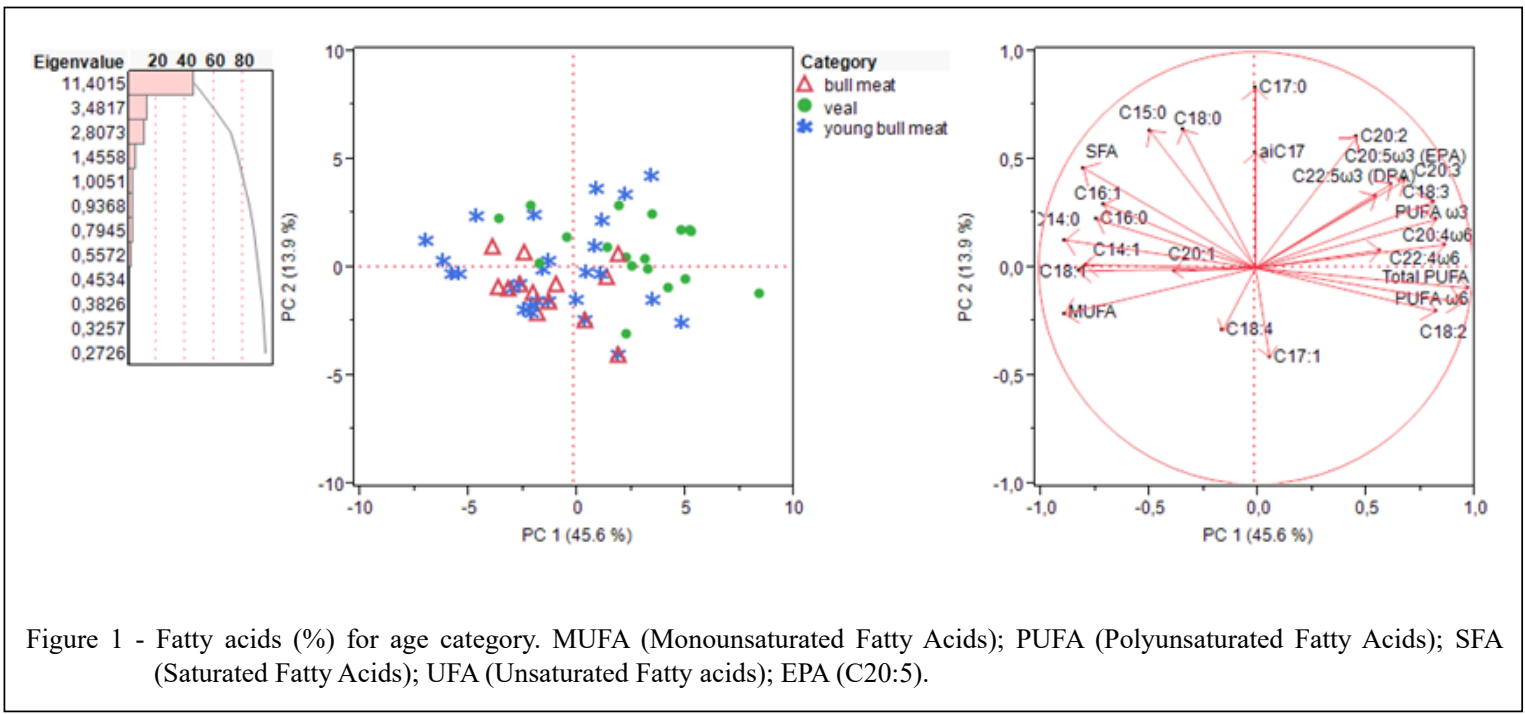

Ciência Rural, v.51, n.7, 2021. 

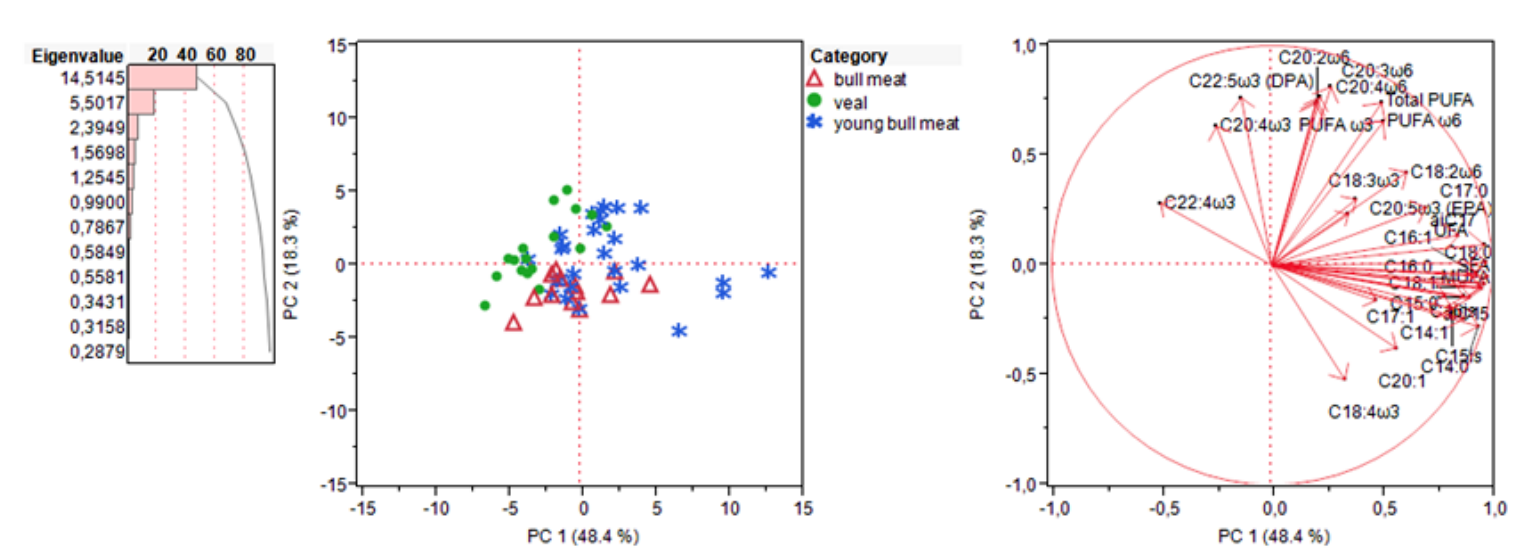

Figure 2 - Fatty acids (mg per 100 gr of Musculus longissimus thoracis) for age category. MUFA (Monounsaturated Fatty Acids); PUFA (Polyunsaturated Fatty Acids); SFA (Saturated Fatty Acids); UFA (Unsaturated Fatty acids); EPA (C20:5).

young bull and bull meat, explaining the $48.4 \%$ of the total variation.

In the PCA for the Healthy Indices (figure 3 ), veal was identified in the left side while young bull and bull meat was clustered together on the upper right square. MUFA/SFA and AI and TI characterized the Maremmana young bull meat. The MUFA, PUFA and SFA content, on the right side, mainly characterized young bull and bull meat.

The PCA Maremmana young bull meat results for MUFA/SFA, AI and TI agreed with the same parameters reported on Fresian young bull meat
(BRUGIAPAGLIA et al., 2013) in a study carried out on Piemontese, Limousin and Fresian young bulls.

The young bull and bull meat results found in PCA for MUFA, PUFA and SFA content, were in accordance with the ANOVA results reported in Holstein, Danish red, Asturana de la Montaña, Piemontese, Simmental and Marchigiana European breeds (SEVANE et al., 2014).

Squared distances among meat typologies, represented by a heat map (Figure 4), distinguished 6 groups. The veal represented the most homogeneous and most distant group,
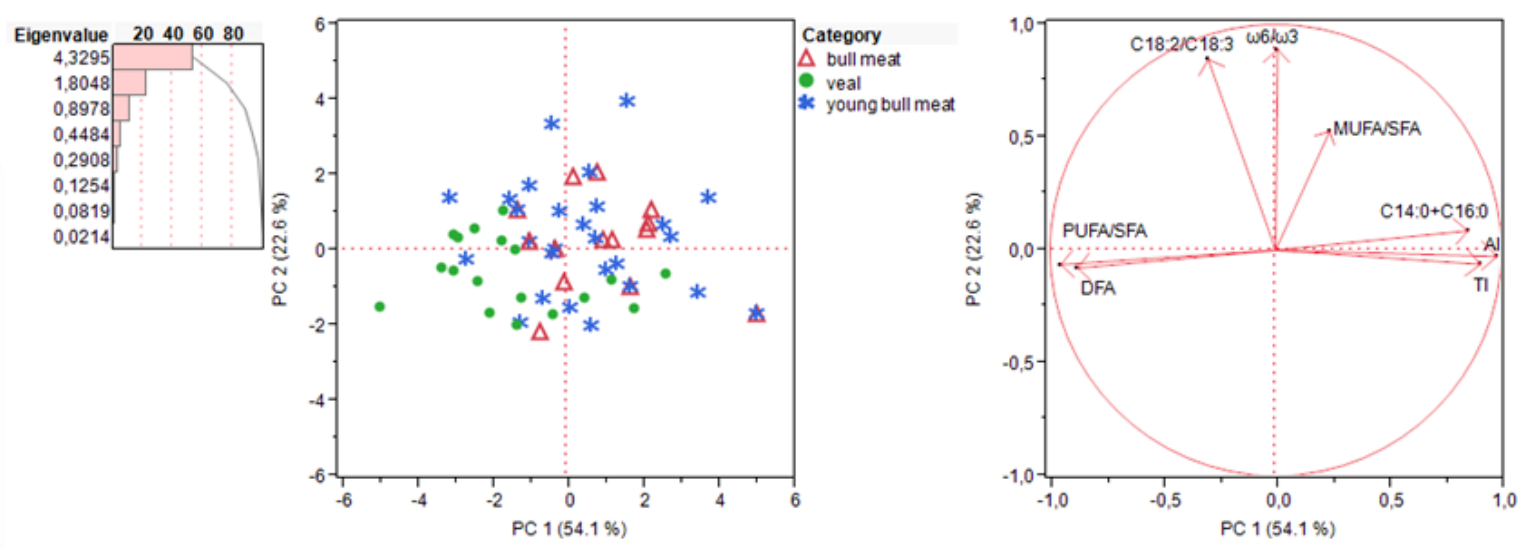

Figure 3 - Healthy Indices for age category. AI (Atherogenicity Index); DFA (Desirable fatty acids); MUFA (Monounsaturated Fatty Acids); PUFA (Polyunsaturated Fatty Acids); SFA (Saturated Fatty Acids); TI (Thrombogenicity Index). 


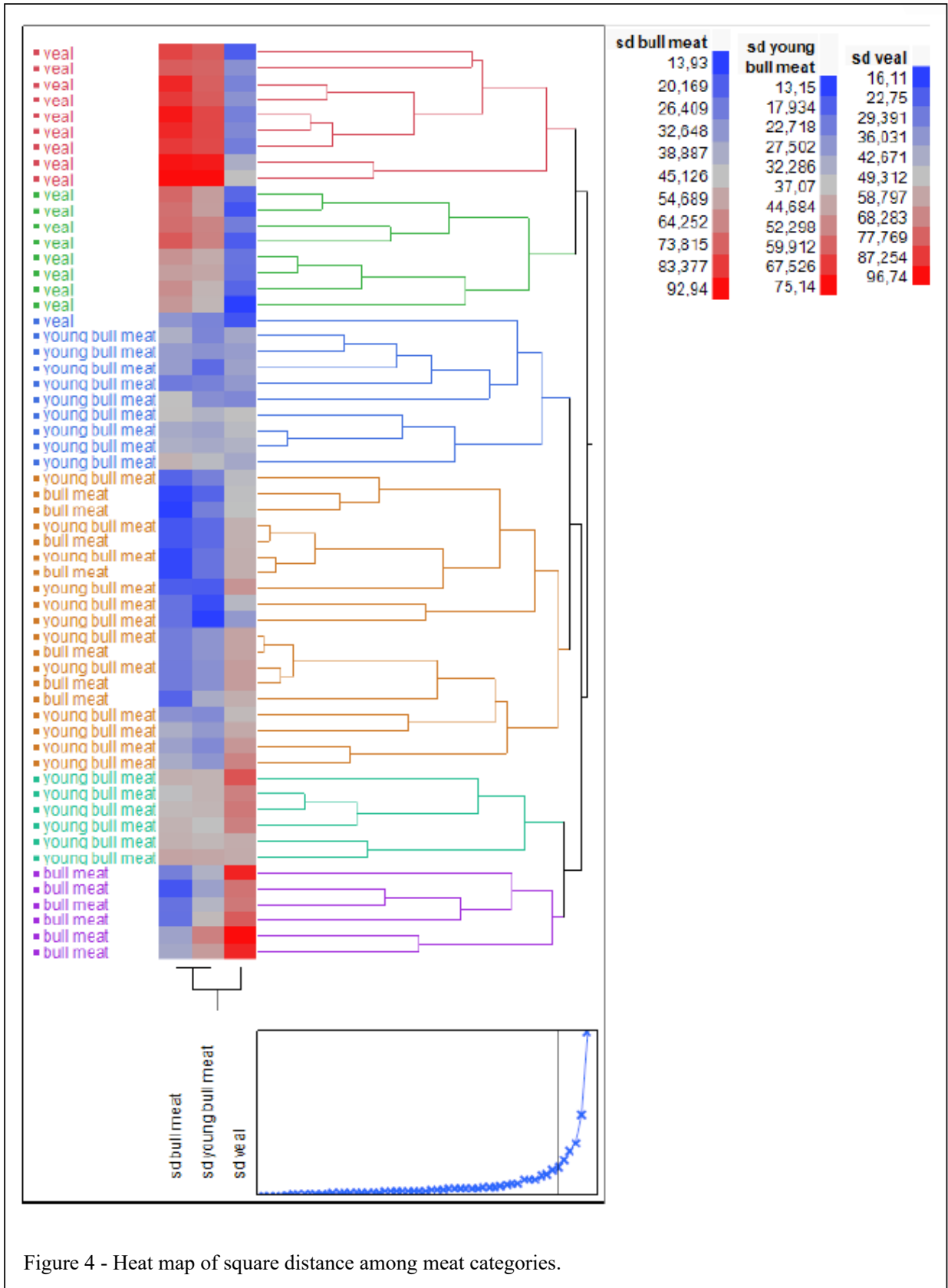

showing high red values. Bull meat has shown the intermediate values, while young bull meat has shown the lowest red values.

\section{CONCLUSION}

The Maremmana cattle meat may be usefully consumed in different at slaughtering classes: 12,18 and 24 months. In fact, the veal was dietetic and richest in PUFA and DFA and showed better AI and TI.

Young bull and bull meat, deriving from animals having better performance at slaughtering, has shown however healthy meat quality, with low SFA levels and good healthy indices. These characteristics are very important in western countries, where a diet rich in fatty acids can influence the incidence of coronary heart diseases and other chronic diseases. 
However, it is important to highlight the low dressing percentage in calves.

The Maremmana meat characteristics are probably due to the great propensity of the breed to an extensive farming system that allows maintaining a healthy diet for the animals in addition to a sustainable livestock management.

\section{BIOETHICS AND BIOSSECURITY COMMITTEE APPROVAL}

We authors of the article entitled " Meat characteristics of Maremmana cattle breed slaughtered at different age" declared, for all due purposes, the project that gave rise to the present data of the same has not been submitted for evaluation to the Ethics Committee of the University /Research Institute "Dipartimento di Scienze e Tecnologie Agrarie, Alimentari, Anbientali e Forestali (DAGRI) - Universitá di Firenze", but we are aware of the content of the Brazilian resolutions of the National Council for Control of Animal Experimentation CONCEA "http://www.mct.gov.br/index.php/content/ view/310553.html" if it involves animals.

Thus, the authors assume full responsibility for the presented data and are available for possible questions, should they be required by the competent authorities.

\section{AKNOWLEDGEMENTS}

This research was supported by Regione Toscana Progetti territoriali di ricerca "Attività di promozione della razza bovina Maremmana attraverso la caratterizzazione della carne e razionalizzazione della filiera" and ex-60\% funds from MURST to the University of Firenze.

\section{DECLARATION OF CONFLICT OF INTEREST}

The authors declare no conflict of interest. The founding sponsors had no role in the design of the study; in the collection, analyses, or interpretation of data; in the writing of the manuscript, and in the decision to publish the results.

\section{AUTHORS' CONTRIBUTIONS}

Conceived and designed the experiments: Clara Sargentini and Davide Rondina. Performed the fieldworks and the laboratory analysis: Clara Sargentini, Davide Rondina, and Antonio b. Analysed and interpreted data: Clara Sargentini and Roberto Tocci. Wrote the paper: Clara Sargentini and Roberto Tocci.

\section{REFERENCES}

AOAC Association of Official Analytical Chemistry, 1990. Official Method of Analysis. 15th ed. AOAC International, Arlington, VA.
ARAÚJO, J. P. et al. Intramuscular fatty Acid composition of the longissimus muscle of unweaned Minhota breed calves at different slaughter age. Iranian Journal of Applied Animal Science, v.20, n.1, p.17-24, 2020. Available from: <http://ijas.iaurasht.ac.ir/ article_671561.html $>$. Accessed: Sep. 18, 2020.

BOZZI, R.; et al. Valorizzazione della razza bovina maremmana: 2 - Caratteristiche fisico-chimiche delle carni. $4^{\text {th }}$ National Congress on Biodiversity: Local germplasm and its valorisation. Proceedings. Alghero (SS), Italy, 1988. p.1061-1064. Available from: <http://www.georgofili.it/download/1199.pdf>. Accessed: Sep. 18, 2020.

CIANI, F.; et al. Bovino Maremmano "Primitivo" ecologia, origine, etologia e allevamento. Taurus, v.21, n.4, p.21-34, 2010. Available from: <http://aspa.unitus.it/matassino/150\%20PDF/ BOVINO\%20MAREMMANO\%20PRIMITIVO\%20Taurus\%20 rev\%20Ciani.pdf $>$. Accessed: Sep. 18, 2020.

DAZA, A.; et al. Effect of gender on growth performance, carcass characteristics and meat and fat quality of calves of Avileña-Negra Ibérica breed fattened under free-range conditions. Spanish Journal of Agricultural Research, v.12, n.3, p.683693, 2014. Available from: <https://dialnet.unirioja.es/servlet/ articulo? codigo $=4863610>$. Accessed: Sep. 18, 2020. doi: $10.5424 /$ sjar/2014123-4693.

DE LA FUENTE, J.; et al. Fatty acid and vitamin E composition of intramuscular fat in cattle reared in different production systems. Meat Science, v.82, n.3, p.331-337, 2009. Available from: <https:// pubmed.ncbi.nlm.nih.gov/20416720/>. Accessed: Sep. 18, 2020. doi: 10.1016/j.meatsci.2009.02.002.

FOLCH, J.; et al. A simple method for the isolation and purification of total lipides from animal tissues. Journal of Biological Chemistry, v.226, p.497-509, 1957. Available from: <https://www. jbc.org/content/226/1/497.full.pdf>. Accessed: Sep. 18, 2020.

HAARMAN, B. C. M.; et al. Feature expression heat maps: a new visual method to explore complex associations between two variable sets. Journal of Biomedical Information, v.53, p.156161, 2015. Available from: <https://www.sciencedirect.com/ science/article/pii/S1532046414002238>. Accessed: Sep. 18, 2020. doi: 10.1016/j.jbi.2014.10.003.

NOGALES, S.; et al. Fatty acid profile of feral cattle meat. Italian Journal of Animal Science, v.16, n.1, p.172-184, 2017. Available from: <https://www.tandfonline.com/doi/full/10.10 80/1828051X.2016.1263163>. Accessed: Sep. 18, 2020. doi: $10.1080 / 1828051 x .2016 .1263163$.

NOGALSKI, Z.; et al. Carcass characteristics and meat quality of bulls and steers slaughtered at two different ages. Italian Journal Animal Science, v.17, n.2, p.279-288 2017. <https://www. tandfonline.com/doi/full/10.1080/1828051X.2017.1383861>. Accessed: Sep. 18, 2020. doi: 10.1080/1828051X.2017.1383861.

SARGENTINI, C. La razza bovina Maremmana come produttrice di carne, mediante allevamento in purezza o in incrocio. In La razza bovina Maremmana. I Georgofili. Quaderni 2011 V - Sezione Centro Ovest - Supplemento a "I Georgofili". Acta. Quaderni dei Georgofili. Serie VIII vol. 8. Innocenti Editore, Grosseto, IT. 2011.

SARGENTINI, C.; et al. Productive Performances of Maremmana Young Bulls Reared Following Organic Rules and Slaughtered at 18 and 24 Months of Age. Italian Journal of Animal Science, 
v.9, p.2, e31, 2010. Available from: <https://www.tandfonline.com/ doi/full/10.4081/ijas.2010.e31>. Accessed: Sep. 18, 2020. doi: 10.4081/ijas.2010.e31.

SARGENTINI, C.; et al. 1996. Performance in vita e post-mortem di vitelli Maremmani puri. Taurus, v.7, p.69-80.

SEVANE, N.; et al. Muscle lipid composition in bulls from 15 European breeds. Livestock Science, v.160, p.1-11. 2014. Available from: <https://www.sciencedirect.com/science/article/pii/ S1871141313004678>. Accessed: Sep. 18, 2020. doi: 10.1016/j. livsci.2013.11.001.

Statistical Analysis Software [SAS]. (2013). SAS/STAT User guide, Version 9.1.1. Cary, NC: SAS Institute Inc.

TARRICONE, S.; et al. Quality characteristics of meats of Podolian bulls slaughtered at different ages. In: IV International symposium of Livestock Production. Proceedings. Struga (Macedonia). 2009, p.168.
TERLER, G.; et al. Schlachtleistung und Fleischqualität von Jungrindern (Fleckvieh $\times$ Limousin und Limousin) aus der Mutterkuhhaltung - Carcass performance and meat quality of young beef (Simmental $\times$ Limousin and Limousin) from suckler cows. Viehwirtschaftliche Fachtagung, v.41, p.85-96. 2014. Available from: <https://www.cabdirect.org/cabdirect/ abstract/20153123119>. Accessed: Sep. 18, 2020.

TOCCI, R.; SARGENTINI, C. Meat quality of Maremmana young bulls. Acta scientiarum. Animal Science, v.42, p.e46515. 2020. Avalable from: <https://www.scielo.br/pdf/ asas/v42/1807-8672-asas-42-e46515.pdf $>$. doi: 10.4025/ actascianimsci.v42i1.46515.

ULBRICHT, T. L. V.; SOUTHGATE, D. A. T. Coronary heart disease: seven dietary factors. Lancet, v.338, p.985-992, 1991. Available from: <https://www.sciencedirect.com/science/article/ abs/pii/014067369191846M>. Accessed: Sep. 18, 2020. doi: 10.1016/0140-6736(91)91846-m. 